\title{
Infection profile of patients undergoing autologous bone marrow transplantation in a Brazilian institution
}

\author{
Perfil de infecção em pacientes submetidos a transplante autólogo de medula \\ óssea em uma instituição brasileira
}

\author{
Kelli Borges Santos', Abrahão Elias Hallack Neto", Girlene Alves Silval', Angelo Atalla"v, Marcus Matta Abreu", Luiz Cláudio Ribeiro"v \\ University Hospital, Universidade Federal de Juiz de Fora (UFJF), Juiz de Fora, Minas Gerais, Brazil
}

\begin{abstract}
'MSc. Assistant Professor, School of Nursing, Universidade Federal de Juiz de Fora (UFJF), Juiz de Fora, Minas Gerais, Brazil.

"PhD. Adjunct Professor, Department of Clinical Medicine, Universidade Federal de Juiz de Fora (UFJF), Juiz de Fora, Minas Gerais, Brazil.

"'PhD. Adjunct Professor, School of Nursing,

Universidade Federal de Juiz de Fora (UFJF), Juiz de Fora, Minas Gerais, Brazil.

"MSc. Adjunct Professor, Department of Clinical Medicine, Universidade Federal de Juiz de Fora (UFJF), Juiz de Fora, Minas Gerais, Brazil.

${ }^{\vee} M D$. Specialist in Thoracic Surgery and Professor of Surgery, Faculdade de Ciências Médicas de Juiz de Fora (FCMS/JF), Juiz de Fora, Minas Gerais, Brazil.

uphD. Demographer and Associate Professor, Department of Statistics, Universidade Federal de Juiz de Fora (UFJF), Juiz de Fora, Minas Gerais, Brazil.
\end{abstract}

\section{KEY WORDS:}

Hematopoietic stem cell transplantation.

Transplantation, autologous.

Infection.

Risk factors.

Infection control.

\section{PALAVRAS-CHAVE:}

Transplante de células-tronco hematopoéticas. Transplante autólogo.

Infecção.

Fatores de risco.

Controle de infecções.

\begin{abstract}
CONTEXT AND OBJECTIVE: Hematopoietic stem cell transplantation (HSCT) has been widely used for treating oncological and hematological diseases. Although HSCT has helped to improve patient survival, the risk of developing infection during hospitalization is an important cause of morbidity and mortality. This study aimed to analyze the infection profile during hospitalization and the associated risk factors among patients undergoing autologous HSCT at the University Hospital, Universidade Federal de Juiz de Fora.

DESIGN AND SETTING: This was a cross-sectional study on patients undergoing autologous HSCT at a public university hospital.

METHODS: Patients with febrile neutropenia between 2004 and 2009 were retrospectively evaluated regarding their infection profile and associated risk factors.

RESULTS: Infection occurred in 57.2\% of 112 patients with febrile neutropenia. The main source of infection was the central venous catheter (25.9\%). Infection was chiefly due to Gram-positive bacteria, although Gram-negative-related infections were more severe and caused a higher death rate. Sex, age, skin color, nutritional status and underlying disease were not associated with the development of infection. Patients with severe mucositis (Grades III and IV) had a higher infection rate $(P<0.001)$. Patients who developed pulmonary complications during hospitalization had higher infection rates $(P=0.002)$. Infection was the main cause of death $(57.1 \%)$ in the study sample.

CONCLUSION: Strategies aimed at reducing infection-related mortality rates among patients undergoing autologous HSCT are necessary.
\end{abstract}

\section{RESUMO}

CONTEXTO E OBJETIVO: O transplante de células-tronco hematopoiéticas (TCTH) vem sendo amplamente utilizado no tratamento das doenças onco-hematológicas. Embora o TCTH tenha colaborado para a melhora na sobrevida dos pacientes, o risco de desenvolver infecção no período de internação é uma importante causa de morbi-mortalidade. O presente estudo teve como objetivo analisar o perfil das infecções no período de internação e os fatores de risco associados entre os pacientes submetidos ao TCTH autólogo, no Hospital Universitário da Universidade Federal de Juiz de Fora.

TIPO DE ESTUDO E LOCAL: Trata-se de um estudo transversal sobre pacientes submetidos a transplante autólogo, em um hospital público universitário.

MÉTODOS: Foram analisados retrospectivamente os pacientes que apresentaram neutropenia febril no período de 2004 a 2009, com relação ao perfil infeccioso e os fatores de risco associados.

RESULTADOS: A infecção foi determinada em 57,2\% dos 112 pacientes com neutropenia febril. A principal fonte de infecção foi o cateter venoso central (25,9\%). A infecção ocorreu principalmente devido a bactérias Gram-positivas, apesar de as infecções causadas por bactérias Gram-negativas terem sido mais graves e causado maior taxa de morte. Sexo, idade, cor da pele, estado nutricional e doença de base não estiveram associados com o desenvolvimento da infecção. Pacientes com mucosite grave (graus III e IV) apresentaram maior taxa de infecção $(P<0.001)$. Os pacientes que desenvolveram complicações pulmonares durante a internação apresentaram maiores taxas de infecção $(P=0,002)$. A infecção foi a principal causa do óbito $(57,1 \%)$ na amostra estudada.

CONCLUSÃO: São necessárias estratégias voltadas para a redução da taxa de mortalidade relacionada com infecção entre pacientes submetidos ao TCTH autólogo. 


\section{INTRODUCTION}

Hematopoietic stem cell transplantation (HSCT) has been widely used for treating oncological and hematological diseases. Although its use has increased patient survival, the risk of infection is an important cause of morbidity and mortality among those undergoing this therapeutic approach. ${ }^{1}$

In spite of lower infection rates with autologous bone marrow transplantation (BMT), in comparison with allogeneic BMT, infection is the second most frequent cause of death among patients undergoing autologous BMT, and is second only to disease relapse.,3

Patient who have undergone autologous BMT are at higher risk of infection during the neutropenia period, and for up to 30 days after bone marrow grafting. The neutropenia period and breach of the mucocutaneous barrier are the main risks for development of infections. ${ }^{4,5}$

Hospital-acquired infection rates among HSCT patients depend on disease severity, drugs used and invasive procedures performed. ${ }^{6}$ Furthermore, the more severe the neutropenia is, the more frequent and aggressive the infections are. ${ }^{4}$

\section{OBJECTIVE}

Taking into account the susceptibility of autologous BMT patients to infection during the neutropenia period, we assessed the infectious events occurring during hospitalization and their associated risk factors.

\section{METHODS}

One hundred and fifteen patients underwent autologous BMT at the University Hospital, Universidade Federal de Juiz de Fora (UFJF), between 2004 and 2009. Of these, 112 patients developed febrile neutropenia, and were analyzed. This study was approved by the research ethics committee of the University Hospital, UFJF.

All patients received antiviral prophylaxis consisting of acyclovir $240 \mathrm{mg} / \mathrm{m}^{2} /$ day, divided into four doses, until they received the graft, and also received granulocyte colony-stimulating factor (G-CSF), $5 \mathrm{mg} / \mathrm{kg} /$ day, in accordance with our local protocol.

Three blood samples were obtained for blood cultures: one from each line of the central venous catheter and one from peripheral blood. Empirical treatment with cefepime ( $4 \mathrm{~g} /$ day, divided into two doses) was instituted for every neutropenic patient with fever.

Febrile neutropenia was considered to be present whenever a patient with a neutrophil count below $500 / \mathrm{mm}^{3}$, or below $1,000 / \mathrm{mm}^{3}$ but predicted to fall to below $500 / \mathrm{mm}^{3},{ }^{7}$ developed a single axillary temperature reading $\geq 38{ }^{\circ} \mathrm{C}$, or two readings $\geq 37.5^{\circ} \mathrm{C}$ within a 12 -hour period. Cultures of samples obtained from different sites were performed whenever a specific infectious site was suspected.

After three days of treatment, the patients were reassessed and, if the fever persisted, a new blood culture was performed. The empirical therapeutic regimen was adjusted in accordance with the recommendations of the Centers for Disease Control and Prevention (CDC). ${ }^{8}$

When blood cultures and cultures from the catheter tip yielded the same organism, with a higher number of colony-forming units (CFU) in the latter, and when the catheter tip culture grew more than $15 \mathrm{CFU}$, the infection was considered to be catheter-related.

For univariate analysis, the chi-square or Fisher exact test was used to determine the association between infection and risk factors (sex, age, underlying disease, duration of neutropenia, drugs used in the conditioning regimen, presence of mucositis, pulmonary complication, diarrhea and sinusoidal obstructive syndrome). Logistic regression was used for multivariate analyses, with the inclusion of variables that presented $\mathrm{P}$ values $<0.05$ on univariate analysis. The Statistical Package for the Social Sciences (SPSS) 13.0 software was used for calculations, and $\mathrm{P}$ values $<0.05$ were considered statistically significant.

\section{RESULTS}

Out of the 115 patients who underwent autologous BMT, 112 developed febrile neutropenia (97.39\%). The median age of this latter group was 43 years (range: 8-69 years). Table 1 shows the characteristics of the study population.

The neutropenia period ranged from four to 25 days (median: nine days). Multiple myeloma patients remained neutropenic for seven days, on average, while those with lymphoma remained neutropenic for 12 days, on average $(\mathrm{P}<0.001)$. Although the difference between the groups was significant, the duration of neutropenia was not associated with occurrences of infection $(\mathrm{P}=0.323)$. There was no impact on the number of infused cells on occurrences of infection $(P=0.129)$.

Six out of 60 patients with positive blood culture had more than one microorganism. Table 2 shows the microorganisms

Table 1. Characteristics of the study population $(n=112)$

\begin{tabular}{|c|c|c|}
\hline Characteristics & $\begin{array}{l}\text { Frequency } \\
\text { (n) }\end{array}$ & $\begin{array}{l}\text { Percentage } \\
\text { (\%) }\end{array}$ \\
\hline \multicolumn{3}{|l|}{ Sex } \\
\hline Male & 64 & 57.1 \\
\hline Female & 48 & 42.9 \\
\hline \multicolumn{3}{|l|}{ Associated comorbidity } \\
\hline Present & 37 & 33.0 \\
\hline Absent & 75 & 67.0 \\
\hline \multicolumn{3}{|l|}{ Underlying disease } \\
\hline Multiple myeloma & 57 & 50.9 \\
\hline Hodgkin's lymphoma & 32 & 28.6 \\
\hline Non-Hodgkin's lymphoma & 18 & 16.1 \\
\hline Neuroblastoma & 02 & 1.8 \\
\hline Acute myeloid leukemia & 03 & 2.7 \\
\hline \multicolumn{3}{|l|}{ Conditioning } \\
\hline $\begin{array}{l}\text { Cyclophosphamide, carmustine and } \\
\text { etoposide }\end{array}$ & 48 & 42.9 \\
\hline Melphalan & 57 & 50.9 \\
\hline $\begin{array}{l}\text { Carmustine, etoposide, cytarabine } \\
\text { and melphalan }\end{array}$ & 5 & 4.5 \\
\hline Others & 2 & 1.8 \\
\hline Total & 112 & 100 \\
\hline
\end{tabular}


Table 2. Frequency of microorganisms isolated from blood cultures

\begin{tabular}{|c|c|c|c|c|c|c|}
\hline Microorganism & $\begin{array}{l}\text { Number of cases in } \\
\text { first blood culture }\end{array}$ & $\%$ & $\begin{array}{l}\text { Number of cases in } \\
\text { second blood culture }\end{array}$ & $\%$ & $\begin{array}{l}\text { Total number } \\
\text { of cases }\end{array}$ & $\%$ total \\
\hline \multicolumn{7}{|l|}{ Gram-positive bacteria } \\
\hline Coagulase-negative Staphylococcus & 23 & 20.0 & 3 & 2.6 & 23 & 20.0 \\
\hline Staphylococcus aureus & 9 & 7.8 & 5 & 4.3 & 11 & 9.5 \\
\hline Streptococcus alpha haemolyticus & 1 & 0.9 & - & - & 1 & 0.9 \\
\hline Total & 32 & 27.8 & 8 & 6.9 & 34 & 29.5 \\
\hline \multicolumn{7}{|l|}{ Gram-negative bacteria } \\
\hline \multicolumn{7}{|l|}{ Enterobacteriaceae family } \\
\hline Klebsiella pneumoniae & 13 & 11.3 & - & - & 13 & 11.3 \\
\hline Escherichia coli & 5 & 4.3 & 1 & 0.9 & 6 & 5.2 \\
\hline Enterobacter cloacae & 5 & 4.3 & - & - & 5 & 4.3 \\
\hline Serratia marcescens & 1 & 0.9 & - & - & 1 & 0.9 \\
\hline \multicolumn{7}{|l|}{ Non-fermenting } \\
\hline Acinetobacter baumanii & 2 & 1.7 & - & - & 2 & 1.7 \\
\hline Pseudomonas aeruginosa & 3 & 2.6 & - & - & 3 & 2.6 \\
\hline $\begin{array}{l}\text { Non-identified non-fermenting gram- } \\
\text { negative bacteria }\end{array}$ & - & - & 1 & 0.9 & 1 & 0.9 \\
\hline Total & 29 & 25.2 & 2 & 1.7 & 31 & 26.9 \\
\hline \multicolumn{7}{|l|}{ Fungi } \\
\hline Candida parapilosis & 1 & 0.9 & 1 & 0.9 & 1 & 0.9 \\
\hline Total & 1 & 0.9 & 1 & 0.9 & 1 & 0.9 \\
\hline Total (all microorganisms) & 62 & 53.9 & 11 & 10.4 & 66 & 57.3 \\
\hline
\end{tabular}

yielded in the first and second blood cultures. One hundred and four different microorganisms were isolated, and the most frequent ones were: coagulase-negative Staphylococcus (24.3\%), Staphylococcus aureus (13\%), Klebsiella pneumoniae (12.1\%), Escherichia coli (9.7\%), Pseudomonas aeruginosa (4.3\%) and Enterobacter cloacae $(4.3 \%)$. There were also isolates of fungi (Candida parapilosis, 0.9\%; Candida albicans, 5.2\%; and Fusarium sp., $0.9 \%$ ) and intestinal parasites (Cryptosporidium spp., 1.7\%; Isospora sp, 0.9\%; and Strongyloides stercoralis, 2.6\%).

Eighty-five instances of infection were identified in 63 patients (57.2\% of the study population), of whom 22 (34.9\%) had a second source of infection. Table 3 shows the sources of infections identified in the study population.

The catheter was the main infection source identified in the study population, and accounted for the infections of 29 patients (25.9\% of the study population). Catheter-related infection was caused by Gram-positive bacteria in $48.3 \%$ of the cases $(\mathrm{P}<0.001)$.

An analysis was made between different risk factors and occurrences of infection. Two cases were taken to be missing data, since it was not possible to determine the occurrence of infection. Table 4 shows the results from this analysis.

Among the 63 patients for whom some kind of microorganism was identified as the cause of their infection, eight (12.6\%) had fungal infection (Candida albicans), 30 (47.6\%) had Grampositive bacteria and 25 (39.6\%) had Gram-negative bacteria. Viral infection due to cytomegalovirus was identified by means of the polymerase chain reaction (PCR) in only one patient.
Table 3. Sources of infection

\begin{tabular}{lcc} 
Characteristics & Frequency $(\mathbf{n})$ & Percentage (\%) \\
\hline Catheter-related infection & 29 & 34.1 \\
\hline Oral candidiasis & 24 & 28.2 \\
\hline Pneumonia & 10 & 11.7 \\
\hline Bacteremia & 05 & 5.8 \\
\hline Urinary infection & 05 & 5.8 \\
\hline Skin infection & 04 & 4.7 \\
\hline Intestinal infection & 04 & 4.7 \\
Systemic fungal infection & 02 & 2.3 \\
Vaginal candidiasis & 02 & 2.3 \\
Total & 85 & 100
\end{tabular}

Oral candidiasis was associated with higher grades (III and IV) of mucositis $(\mathrm{P}<0.001)$. Two patients developed fungemia: one due to Candida parapilosis and one due to Fusarium spp. Fungi (Cryptosporidium spp. and Isospora spp.) were isolated from the stools of two patients.

Mycobacterium tuberculosis grew in a culture from secretions obtained from a cutaneous abscess. Out of the 104 microorganisms isolated, nine $(8.6 \%)$ were cefepime-resistant. Although three (21.4\%) of the Staphylococcus aureus isolates were methicillin-resistant (MRSA), they were uniformly sensitive to vancomycin. Blood cultures from six patients presented oxacillin-resistant coagulasenegative Staphylococcus.

Among the eight patients who died of infection, three (37.5\%) presented Gram-negative bacteria in their cultures, one had Fusarium spp. and four had no growth in the cultures performed. 


\section{Infection-associated factors}

Mucositis $(P=0.04)$ and pulmonary complications $(P=0.002)$ during hospitalization were the only variables with a statistically significant impact on the occurrence of infection, on univariate analysis. Patients with higher grades (III and IV) of mucositis developed infections more frequently $(\mathrm{P}=0.02)$.

Patients with associated comorbidities, such as diabetes mellitus and systemic arterial hypertension, were more likely to develop infection, although this was not statistically significant $(\mathrm{P}=0.05)$.

Both variables that showed statistical significance in relation to infection on univariate analysis (mucositis and pulmonary complications) were included in the logistic regression models.
The results from this model are shown in Table 5. Only pulmonary complications remained an independent risk on multivariate analysis $(P=0.015)$, with an odds ratio of 13 . Although the confidence interval of the odds ratio for the variable of pulmonary complications was large, this was due to the low frequency of events. Nonetheless, 14 out of the 15 individuals who had pulmonary complications developed infections, which shows that there was a strong association between these variables. Even though the $\mathrm{P}$ value related to mucositis was slightly above $5 \%$, stratified analysis showed that among individuals who did not have pulmonary complications, the infection rate was significantly higher among patients who developed mucositis $(\mathrm{P}=0.032)$.

Table 4. Factors associated with infection during hospitalization*

\begin{tabular}{|c|c|c|c|c|}
\hline Features analyzed & Total & Presence of infection & $\%$ & $\mathbf{P}$ \\
\hline \multicolumn{5}{|l|}{ Conditioning } \\
\hline Cyclophosphamide, carmustine and etoposide & 46 & 25 & 54.3 & \multirow{4}{*}{0.600} \\
\hline Melphalan & 56 & 32 & 57.1 & \\
\hline Carmustine, etoposide, cytarabine and melphalan & 6 & 5 & 83.3 & \\
\hline Others & 2 & 1 & 50.0 & \\
\hline \multicolumn{5}{|l|}{ Underlying disease } \\
\hline Lymphomas & 48 & 27 & 56.3 & \multirow{3}{*}{0.575} \\
\hline Myeloma & 57 & 32 & 56.1 & \\
\hline Others & 5 & 4 & 80.0 & \\
\hline \multicolumn{5}{|l|}{ Associated comorbidity } \\
\hline Present & 37 & 26 & 70.3 & \multirow{2}{*}{0.050} \\
\hline Absent & 73 & 37 & 50.7 & \\
\hline \multicolumn{5}{|l|}{ Mucositis } \\
\hline Present & 59 & 39 & 66.1 & \multirow{2}{*}{0.044} \\
\hline Absent & 51 & 24 & 47.1 & \\
\hline \multicolumn{5}{|l|}{ Degree of mucositis } \\
\hline I & 24 & 11 & 45.8 & \multirow{4}{*}{0.020} \\
\hline II & 19 & 14 & 73.7 & \\
\hline III & 14 & 12 & 85.7 & \\
\hline IV & 2 & 2 & 100.0 & \\
\hline \multicolumn{5}{|l|}{ Diarrhea } \\
\hline Present & 72 & 39 & 54.2 & \multirow{2}{*}{0.365} \\
\hline Absent & 38 & 24 & 63.2 & \\
\hline \multicolumn{5}{|l|}{ Sinusoidal obstruction syndrome } \\
\hline Present & 6 & 4 & 66.7 & \multirow{2}{*}{0.632} \\
\hline Absent & 104 & 59 & 56.7 & \\
\hline \multicolumn{5}{|l|}{ Pulmonary complications } \\
\hline Present & 15 & 14 & 93.3 & \multirow{2}{*}{0.002} \\
\hline Absent & 95 & 49 & 50.0 & \\
\hline \multicolumn{5}{|l|}{ Sex } \\
\hline Female & 47 & 30 & 63.8 & \multirow{2}{*}{0.230} \\
\hline Male & 63 & 33 & 52.4 & \\
\hline
\end{tabular}

"Missing: two patients without data on infection.

Table 5. Multivariate analysis with risk factors for infection*

\begin{tabular}{lcccc} 
Variables & P-value & Odds ratio & \multicolumn{2}{c}{ 95\% confidence interval } \\
Mucositis & 0.054 & 2.21 & Lower & Upper \\
Pulmonary complications & 0.015 & 13.23 & 1.65 & 4.94 \\
\hline
\end{tabular}

*Adjusted for mucositis and pulmonary complications. 


\section{DISCUSSION}

In this study, $57.2 \%$ of the population had an infection identified during hospitalization. According to published data from a single Brazilian center, the infection rate among a pediatric population undergoing allogeneic and autologous BMT was $58.5 \% .{ }^{9}$ In a multicenter study undertaken in southern and southeastern Brazil, the infection rate was $55 \%{ }^{2}$ Although these values are similar to ours, the comparison is hampered because we studied patients undergoing autologous BMT alone.

Studies in other countries on patients undergoing autologous BMT have indicated infection rates ranging from $27.6 \%$ to $48.2 \%,{ }^{10,11}$ i.e. lower than the rate that we found. Although not statistically significant, there was a difference in the occurrence of infection in relation to the first years covered by this study. This might be accounted for by the little experience of managing autologous BMT patients that existed in those early days, which may have led to infection rates that were higher than those in the literature.

In disagreement with the literature, ${ }^{5,12,13}$ age was not associated with the risk of infection in our study. This finding was possibly due to the small number of children in our sample.

In agreement with the findings of Poutsiaka et al. ${ }^{14}$ the length of the neutropenia period was not significantly associated with higher rates of infectious complications in our study. The same was observed in the study by Ninin et al. ${ }^{15}$ in which patients undergoing autologous and allogeneic BMT had similar infection rates.

Although not statistically significant, multiple myeloma patients had the lowest infection rates, a finding that is similar to the data reported by Meyer et al. ${ }^{16}$ According to Gil et al., ${ }^{10}$ acute myeloid leukemia patients undergoing autologous BMT have the highest risk of infection, since they remain neutropenic for longer periods. In our study, there was no association between the conditioning regimen and infection.

The most common infection source was the catheter $(34.1 \%)$. Our data were very close to those of Nucci and Maiolino, ${ }^{2}$ who reported a catheter-related infection rate of $38 \%$ in their patients. The associated factors may include: handling frequency, insertion site, contamination during insertion, skin colonization around the insertion site, contamination of the connection device between the infusion system and vascular access, contamination of the infusion fluid, contamination of solutions used to ensure catheter permeability and presence of distant infectious sites with hematogenic spread of infection. ${ }^{4,8}$

We also made this observation, such that patients with mucositis of grades III and IV had higher infection rates.

Infection-related pulmonary complications have been considered to be important determiners of morbidity and mortality. According to Meyer et al., ${ }^{16}$ pneumonia was the second most frequent cause of infection in these patients, occurring in $7.8 \%$ of the cases. According to Dettenkofer et al., ${ }^{6}$ pneumonia is the most frequent infection in patients undergoing autologous BMT.

Three patients had oxacillin-resistant Staphylococcus aureus. This microorganism increases the infection-related mortality rate of grafted patients, and has been isolated with higher frequency, in different places, over the past few years. ${ }^{17}$ No vancomycin-resistant microorganism was isolated in our study.

In accordance with the Brazilian and foreign literature, Gram-positive bacteria were the most frequent isolates in our study. Nonetheless, a significant increase in the number of infections due to Gram-negative bacteria has been reported over the past few years. ${ }^{17,12,18-21}$ This may be accounted for by greater use of prophylactic antimicrobials, chiefly quinolones. ${ }^{22}$

According to Laws et al., ${ }^{19}$ Gram-negative bacterial infections are more severe and cause higher death rates, compared with Gram-positive bacterial infections. This may be explained by their greater virulence and resistance, and the latter is also due to their double cell membrane, which blocks the entry of some drugs. ${ }^{23}$

The most frequent isolate in our study was coagulase-negative Staphylococcus, in agreement with findings from different BMT centers. ${ }^{6,15,16,19,24,25}$ Until recently, these bacteria were considered contaminants, devoid of serious clinical importance. ${ }^{26}$ However, over the past few years, they have been acknowledged as important infectious agents. Catheters are the main means of entry for these microorganisms. ${ }^{26}$

Fungi were the second most frequently identified microorganisms in the infections we found. The main isolate was Candida albicans, and its presence was associated with mucositis. In autologous BMT, the likelihood of systemic candidiasis is very low, and occurs chiefly after the neutropenia period has resolved, or in the absence of mucositis. ${ }^{27}$

Similarly to findings from other centers, ${ }^{2,8,11,14}$ infection was the main cause of death in our patients during hospitalization. It seemed to contribute towards longer hospital stay, although this association did not present statistical significance $(\mathrm{P}=0.081)$.

\section{CONCLUSIONS}

The infection rate found among patients undergoing BMT was high $(57.2 \%)$, and the main source was the catheter (34.1\%). We believe that continuing training programs and basic preventive measures, targeted to reduce infectious complications during the hospitalization of patients undergoing BMT, are paramount. Further studies are necessary before more effective measures to protect this infection-prone population can be implemented. 


\section{REFERENCES}

1. Naoum FA, Martins LTV, Castro NS, Barros JC, Chiattone CS. Perfil microbiológico dos pacientes nos primeiros trinta dias pós transplante de medula óssea do Serviço de Transplantes da Santa Casa de São Paulo [Microbiological profile of patients in the first thirty days post bone marrow transplantation of the Transplantation Service in Santa Casa, São Paulo]. Rev Bras Hematol Hemoter. 2002;24(2):91-6.

2. Nucci M, Maiolino A. Infecções em transplante de medula óssea. [Infection in bone marrow transplant recipients]. Medicina (Ribeirão Preto). 2000;33(3):278-93.

3. Bueno ND, Saboya R, Martins MC, et al. O transplante de medula óssea na leucemia mielóide aguda: análise de 80 pacientes transplantados no complexo do Hospital das Clínicas da Faculdade de Medicina da Universidade de São Paulo [The allogeneic and autologous bone marrow transplantation in acute myeloid leukemia: analysis of 80 patients - Bone Marrow Transplantation Service - Hospital das Clínicas of the Medical School, University of São Paulo]. Rev Bras Hematol Hemoter. 2004;26(2):84-92.

4. Dykewicz CA; Centers for Disease Control and Prevention (U.S.); Infectious Diseases Society of America; American Society of Blood and Marrow Transplantation. Summary of the Guidelines for Preventing Opportunistic Infections among Hematopoietic Stem Cell Transplant Recipients. Clin Infect Dis. 2001;33(2):139-44.

5. Mackall C, Fry T, Gress R, et al. Background to hematopoietic cell transplantation, including post transplant immune recovery. Bone Marrow Transplant. 2009;44(8):457-62.

6. Dettenkofer M, Wenzler-Röttele $S$, Babikir $R$, et al. Surveillance of nosocomial sepsis and pneumonia in patients with a bone marrow or peripheral blood stem cell transplant: a multicenter project. Clin Infect Dis. 2005;40(7):926-31.

7. Hughes WT, Armstrong D, Bodey GP, et al. 2002 guidelines for the use of antimicrobial agents in neutropenic patients with cancer. Clin Infect Dis. 2002;34(6):730-51.

8. Centers for Disease Control and Prevention; Infectious Diseases Society of America; American Society of Blood and Marrow Transplantation. Guidelines for preventing opportunistic infections among hematopoietic stem cell transplant recipients. MMWR Recomm Rep. 2000;49(RR-10):1-125, CE1-7.

9. Castro Júnior CG, Gregianin LJ, Brunetto AL. Análise clínica e epidemiológica do transplante de medula óssea em um serviço de oncologia pediátrica [Clinical and epidemiological analysis of bone marrow transplantation in a pediatric oncology unit]. J Pediatr (Rio J). 2003;79(5):413-22.

10. Gil L, Styczynski J, Komarnicki M. Infectious complication in 314 patients after high-dose therapy and autologous hematopoietic stem cell transplantation: risk factors analysis and outcome. Infection. 2007:35(6):421-7.

11. Reich G, Mapara MY, Reichardt P, Dörken B, Maschmeyer G. Infections complications after high-dose chemotherapy and autologous stem cell transplantation: comparison between patients with lymphoma or multiple myeloma and patients with solid tumors. Bone Marrow Transplant. 2001;27(5):525-9.

12. Bailey LC, Reilly AF, Rheingold SR. Infections in pediatric patients with hematologic malignancies. Semin Hematol. 2009;46(3):313-24.

13. Mendes AVA, Sapolnik R, Mendonça N. Novas diretrizes na abordagem clínica da neutropenia febril e da sepse em oncologia pediátrica [New guidelines for the clinical management of febrile neutropenia and sepsis in pediatric oncology patients]. J Pediatr (Rio J.). 2007; 83(2, supl.): S54-S63.

14. Poutsiaka DD, Price LL, Ucuzian A, et al. Blood stream infection after hematopoietic stem cell transplantation is associated with increased mortality. Bone Marrow Transplant. 2007;40(1):63-70.

15. Ninin E, Milpied N, Moreau P, et al. Longitudinal study of bacterial, viral, and fungal infections in adult recipients of bone marrow transplants. Clin Infect Dis. 2001;33(1):41-7.

16. Meyer E, Beyersmann J, Bertz $\mathrm{H}$, et al. Risk factor analysis of blood stream infection and pneumonia in neutropenic patients after peripheral blood stem-cell transplantation. Bone Marrow Transplant. 2007;39(3):173-8.

17. Shaw BE, Boswell T, Byrne JL, Yates C, Russell NH. Clinical impact of MRSA in a stem cell transplant unit: analysis before, during and after an MRSA outbreak. Bone Marrow Transplant. 2007;39(10):623-9.

18. Oliveira AL, de Souza M, Carvalho-Dias VM, et al. Epidemiology of bacteremia and factors associated with multi-drug-resistant gram-negative bacteremia in hematopoietic stem cell transplant recipients. Bone Marrow Transplant. 2007;39(12):775-81.

19. Laws HJ, Kobbe G, Dilloo D, et al. Surveillance of nosocomial infections in paediatric recipients of bone marrow or peripheral blood stem cell transplantation during neutropenia, compared with adult recipients. J Hosp Infect. 2006;62(1):80-8.

20. Moura MEB, Campelo SMA, Brito FCP, et al. Infecção hospitalar: estudo de prevalência em um hospital público de ensino [Nosocomial infection: study of prevalence at a public teaching hospital]. Rev Bras Enferm. 2007;60(4):416-21

21. Walsh T.J. Advances and challenges in infectious diseases supportive care of patients with hematologic malignancies, hematopoietic stem cell transplantation, and severe aplastic anemia. Semin Hematol. 2009;46(3):191-7.

22. Cattaneo C, Quaresmini G, Casari S, et al. Recent changes in bacterial epidemiology and the emergence of fluoroquinolone-resistant Escherichia coli among patients with haematological malignancies: results of a prospective study on 823 patients at a single institution. J Antimicrob Chemother. 2008;61(3):721-8.

23. Alterthun F. Morfologia e estrutura da célula bacteriana. In: Trabulsi LR, Alterthun F, editors. Microbiologia. São Paulo: Atheneu; 2008. p. 1-19.

24. Çelebi H, Akan H, Akçağlayan, Ustün C, Arat M. Febrile neutropenia in allogeneic and autologous peripheral blood stem cell transplantation and conventional chemotherapy for malignancies. Bone Marrow Transplant. 2000;26(2):211-4.

25. Toor AA, van Burik JA, Weisdorf DJ. Infections during mobilizing 
chemotherapy and following autologous stem cell transplantation. Bone Marrow Tranplant. . 2001;28(12):1129-34.

26. Bueris V, Moreira CG, Teixeira LM, Santos KRN, Trabulsi LR. Staphylococcus epidermidis e outras espécies de Staphylococcus, micrococcus e Rothia (Stomatococcus). In: Trabulsi LR, Alterthum F, editors. Microbiologia. São Paulo: Atheneu; 2008. p. 183-7.

27. Marr KA, Bow E, Chiller T, et al. Fungal infection prevention after hematopoietic cell transplantation. Bone Marrow Transplant. 2009;44(8):483-7.

Sources of funding: None

Conflict of interest: None

Date of first submission: January 10, 2011

Last received: July 13, 2011

Accepted: July 20, 2011

\section{Address for correspondence:}

Kelli Borges Santos

Joaquim Carneiro Filho, 45/501

Cascatinha — Juiz de Fora (MG) — Brasil

CEP 36033320

E-mail: kelli.borges@yahoo.com.br 